ROCZNIKI HUMANISTYCZNE

Tom LXVI, zeszyt $11-2018$

ZESZYT SPECJALNY/SPECIAL ISSUE

DOI: http://dx.doi.org/10.18290/rh.2018.66.11s-5

JUSTYNA GALANT

\title{
LABORATORIES OF CIRCUMSTANCES AND MISSHAPEN TRANSHUMANS: FAILURES OF PERFECTIBILITY IN TWO NINETEENTH-CENTURY AMERICAN DYSTOPIAS
}

\begin{abstract}
The article is an analysis of two early American nineteen-century dystopias, The Man Machine, or the Pupil of Circumstances (1826) by James Kirke Paulding and A Sojourn in the City of Amalgamation in the Year of our Lord 19-- (1835) by Jerome Bonaparte Holgate, focusing on the presentation of early versions of transhumans in the works. While Paulding's novella focuses on criticism of Robert Owen's New Lanark, a textile factory and a socialist experiment, and Holgate's satire addresses the question of miscegenation, they both foreground the concept of the new human as a product of the respective reformers' misguided ideologies.
\end{abstract}

Key words: ideology; racism; Owenism; transhuman.

Two early nineteenth-century American texts-The Man Machine, or the Pupil of Circumstances by James Kirke Paulding from 1826 and A Sojourn in the City of Amalgamation in the Year of our Lord 19-- by Jerome Bonaparte Holgate writing under the pseudonym Oliver Bolokitten in 1835seem to be the rare English-language dystopias ${ }^{1}$ of the century which feature some form of transhumans. Created at the dawn of "a golden age of utopianism" (Roemer 79) in all its facets (social theory, intentional communities and literary output), the two works respond to the major challenge of the nineteenth century-human perfectibility. Paulding's novella is concerned with the production of a happier, more educated, more ethical, healthier human and a more efficient worker; Holgate's racist satire with the making of a technologically and psychologically modified human who (exclusively due

Justyna Galant, PhD — Maria Curie-Skłodowska University, Faculty of Humanities, Institute of English Studies; address for correspondence: Plac Marii Skłodowskiej-Curie 4A, 20-031 Lublin; e-mail: justynagalant@gmail.com

${ }^{1}$ In calling both texts dystopias I adopt Artur Blaim's view that "anti-utopia [can] be seen as a certain function or [...] use of the dystopian text, and not a literary genre" (88). 
to such interference) finds miscegenation natural and desirable. As from the authors' perspectives the transhumans-Paulding's perfect Owenite worker/ human being and Holgate's race-blind citizen-are recognised as unsound issues of misguided minds, the texts dramatise the righteous struggle of human nature against transformative powers and exorcise their creators' fears through extensive use of mockery. Notably, in both works the key role in the attempted advancement of a human to a higher level is played not by technology - typically identified as the chief tool in such transformationbut by ideology and indoctrination. Written during an age of faith in various large-scale projects for the improvement of mankind, these nineteenth-century examples of the dystopian genre recognise the greatest capacity for change in what their authors see as dangerous ideas.

The Man-Machine is an anti-Owen novella never identifying the man in question by name yet quoting verbatim from his book $A$ New View of Society. Narrated by a man employed in factories from his early childhood and a member of Robert Owen's New Lanark from around the age of ten, the text records the failure of the philanthropist's endeavours and the protagonist's futile efforts to become a perfect member of the establishment, then a successful leader of his own communities. Its author, a prolific satirist ${ }^{2}$ and politician who rose to become Secretary of the Navy (1838-41), together with Washington Irving and William Irving published the satirical periodical Salmagundi; or The Whim-whams and Opinions of Launcelot Langstaff, Esq. \& Others, in circulation for about a year from 1807, which gave New York City its nickname of Gotham. Written three years before Carlyle's famous warning against The Age of Machinery ${ }^{3}$, but well after the poet's direct inspiration, Schiller's Letters Upon the Aesthetical Education of Man (1795), ${ }^{4}$ Paulding's anti-utopia voices concerns about the position of work-

\footnotetext{
${ }^{2}$ Aderman discusses Paulding as a keen observer and critic of his times, and especially of America, focusing primarily on his journalistic output.

${ }^{3}$ Carlyle's essay contains imagery similar to Paulding's vision where mechanisation concerns mind, body and community: "Men are grown mechanical in head and in heart, as well as in hand. [...] Their whole efforts, attachments, opinions, turn on mechanism, and are of a mechanical character" (Carlyle 4).

${ }^{4}$ Schiller's contemplation of a reified, alienated human bears strong resemblance to Paulding's description of machine addiction: "Man himself eternally chained down to a little fragment of the whole, only forms a kind of fragment; having nothing in his ears but the monotonous sound of the perpetually revolving wheel, he never develops the harmony of his being; and instead of imprinting the seal of humanity on his being, he ends by being nothing more than the living impress of the craft to which he devotes himself, of the science that he cultivates" (Schiller 8); "From long watching the eternal round of the spinning jenney, its action became so impressed on the pupil of my eyes, and its buzzing noise upon the drum of my ear, that present or absent,
} 
ers within the thriving industrial system, which some time later will be articulated in a revolutionary spirit by Engels and Marks.

The other text, written less than a decade later by a genealogist (and the author of another speculative fiction, the lost-race story Noachida: Or, Noah and His Descendants), is a virulently racist menippean dystopia offering the view of a city where black people enjoy more respect than white, the races are encouraged to intermarry and all prejudices, in humans and animals alike, are actively counteracted. Presumably "the first work of American fiction to treat miscegenation as its central issue" (Martin 71), A Sojourn in the City of Amalgamation is narrated by a dreamer who finds the state of affairs ridiculous and appalling.

\section{TRANSHUMAN GROTESQUES AND THE RESISTING BODY}

These two dystopias portray their preposterous altered humans as victims of ideas, positing them as trouble become flesh and amply employing grotesquery to drive the point home. The resulting human caricatures are both walking exempla of the transformative power of ideologies and testimonies to their essential falsehood-ridiculousness and ugliness become signs of the impossibility to produce an ideal on faulty grounds.

In Paulding, strikingly, Robert Owen's multi-faceted utopian scheme of a fair, equal, educated, mutually caring community is reduced to an existence by rote: "Our perfectibility at last centered exclusively in the performance of our daily duties" (63). It is also cynically interpreted in financial terms, total identification of the anticipated transhumans and technology being an aim in the service of a capitalist ideal expressed by the fictitious Owen himself:

'I consider', said he, 'the people employed in my establishment as a part of the machinery, the whole of which is my duty and interest to combine, so that every hand, as well as every spring, lever and wheel, shall effectually co-operate to produce the greatest pecuniary gain to the proprietors, which is what I understand by the perfectibility of the Man Machine'. (27)

sleeping or waking, my brain retained no other image. The wheel was perpetually dancing before me; and as a man after looking at the bright sun in the firmament [...] sees when he withdraws his eyes a thousand orbs dancing before him, so did I a thousand spinning jenneys" (Paulding 82).

${ }^{5}$ Though the italicised fragment is quoted directly from A New View of Society, Paulding chooses to disregard the fact that it is part of an essay addressed to businessmen and so cast in terms appropriate to the concerns of those readers. The comparison of a human to a machine may sound jarring, but it may also be a clever strategy to appeal for reforms, taking into account the specificity of the group which have a say in implementing them. 
In the writer's vision the eponymous man-machine is not a cyborg but a human self-identifying as a machine as a result of perpetual hard labour in the textile industry. As the narrator informs us, "By the time I had been [in a factory] three years, I became sensible that my soul had transmigrated into a spinning jenney, and that I had actually become a piece of machinery" (24). Having spent time in Owen's establishment, where the previously acquired habits are honed to accord with the philanthropist's ideas, the protagonist, along with the community, undergoes further mechanisation, relinquishing individuality and at all times holding instincts at bay until all passion wanes:

'I had at last become a model [...] of a perfect Man Machine. I had neither virtues to exercise, nor counteracting principles to lead me astray. I worked my task as regularly as spinning jenney went through hers: I ate like a machine [...] I slept by rule, rose by rule, and did every thing by rule.[...] In process of time our whole community also arrived at a perfectibility that was truly astonishing considering its apparent impossibility. It might be said that we had neither virtues nor vices [...] There is no doubt that we all became quite perfect. (63)

In the satirist's version of New Lanark, the mechanising transformation into a "better" human also involves the loss of self-determination:

They took care of our morals, our manners, and our money, while we, thrice happy machines, had nothing to do but move ourselves about, with all the regularity of a spinning jenney - we worked by rule, ate by rule, slept by rule, and were as merry as so many cabbages, growing in regular lines. (65)

To the philanthropist's and the workers' disappointment, the constant training in equality and "self-love" (understood as selflessness) cannot entirely eradicate the passionate impulses which disrupt the grand scheme. Visible in all walks of the communal life, during supervised playground games, in neighbourly interactions, or in love affairs, impulsive needs repeatedly take the upper hand: "My master's indefatigable enemies, the 'counteracting principles,' were in fact continually at work, throwing stumbling-blocks in the way of our perfectibility, and going about like roaring lions among us" (44).

A similar dedication to the cause which prompts the need for human transformation suffuses the streets of Holgate's City of Amalgamation, where the population suffers a rather painful and, in the long run, ineffective interference with the body, specifically, its violation or temporary outward change, to produce racially tolerant citizens. While black people are lashed and fumigated to rid their bodies of an alleged odour unbearable to whites, 
the latter are subject to the process of "bottling" during which fragrancefilled contraptions in the form of a cow's udder are attached to their nose hair. This rudimentary form of cyborg is appropriately ridiculed through carnivalesque associations when its quasi-scientific description is juxtaposed with the unsavoury subject matter:

\begin{abstract}
the menials summoned, appeared, having long rods resembling wire, to the end of which were attached small claws, with which they hitched the perfume pouch to the nose by means of the hairs which garnished each. This singular bottle then dangled at the novitiate's proboscis, always ready to supply every lack of odour.

'There'! cried Wildfire, [...] letting go the pouch, he stepped back, leaving it dangling at the novice's nostril, 'It is finished. A delicate operation, Mr. Hoffle. It looks queer, sir, at first; but it is a common thing; half of the folks in the city are bottled'. (Holgate 41)
\end{abstract}

As in Paulding's work, the violated minds and bodies resist the alien influences. Despite their best efforts, even while intently listening to preaching about racial equality, believers in amalgamation still vomit uncontrollably and profusely in the presence of their black fellow citizens; a man de-bottles in his sleep; and a white girl cannot help but loath a black suitor, etc. Appropriately, the central fear of the text-contaminating cross-breeding-is most memorably expressed in the posthuman creation of a racist nightmare-cometrue: a freak-show exhibit of Boge Bogun, a man literally half white and half black, divided with a clear line in the middle - a monstrous warning against miscegenation. ${ }^{6}$ The auto-immune reaction within Boge's body, described by him in his memoirs as a long war between the black and white "particles of the flesh," not only anticipates the American civil war but also reflects the metaconflict common to this novel and Paulding's - that between nature and ideology.

\title{
LOW-TECH MEANS TO IDEOLOGICAL END
}

In both texts the sinister, transformative character of philanthropy and race-blindness is strengthened through their link with technology, proffering ideology and technology as allies against reasonable and instinctive human nature. In Paulding, machinery is intrinsically connected with industrial-

\footnotetext{
${ }^{6}$ Holgate is clearly inspired by freak-show exhibits of so-called "Leopard Children," pigmented both black and white, which, as Martin points out, along with "the fantasy of the Negro Turning White" (72) are strongly present in abolition debates.
} 
capitalist abuses and its resulting de-humanisation ${ }^{7}$, while in Holgate, in a more medieval fashion, with religion and torture. Association with the mechanical kills two birds with one stone-it employs the negative connotation of technology escalating throughout the industrial era to strengthen the sense of threat, and, by marrying the body to the machine, it produces an image of the violated, machine-tainted human to juxtapose with the natural human form.

Notably, although technology is obviously negatively connoted, it is not perceived as almighty, beyond an ordinary human's comprehension and control, as is often the case in modern-day posthuman dystopias. It is, in fact, extremely rudimentary, if not homey, the central device in Man-Machine being the spinning-jenny and the key processes employed in Sojourn being boiling and fuming.

Although the narrator of Man-Machine describes the actions and routines of the Owenite community as mechanical, his reference to the dull sameness of its inhabitants characterizes them also by means of a rather different simile - the afore-mentioned rows of cabbages. The juxtaposition of the two images seems to suggest machines are by no means an overwhelming, dominant power, but rather, much like Owen's preaching to his people, exert their influence by being a constant feature in the life of the community and, as such, becoming a part of the habit-forming mechanisms employed therein. Essentially, in Paulding's cautionary tale, imitation of machinery produces unreflective humans whose driving characteristics are mindless repetitiveness and the resulting impairment of cognitive functions which facilitates absorption of the philanthropist's perilous ideas. Consequently, then, this dystopia, rather originally for a transhumanist text, depicts the appropriation of a machine's central feature through its imitation, showing how humanity transforms into its new version unthinkingly, by the force of habit. In this manner Paulding manages to condense Owen's scheme for improvement of the human condition into a highly reductive ideology of thoughtless repetitiousness, with the spinning jenny as its key metaphor. The transhuman is not a product of the wizardry of new human inventions, but a by-product of changing times and a victim of circumstance-facilitated indoctrination.

In Holgate's work, the low-tech machinery relies entirely on controlled manpower, and the hellish atmosphere of the "boilers" and "perfumeries" blends medieval-seeming torture-equipment with only a dash of scientific modernity. The operation of the instruments is directly related to the arduous

\footnotetext{
${ }^{7}$ Gerber observes that Paulding "may be the first important American literary figure to use the machine image as a composite sign of the times" (741).
} 
work of worshippers of the Goddess Enthusiasm, forging a strong, hierarchical link between faith in the cause and its aide-the machine. The dependent role of technology in Amalgamation is also tellingly illustrated by the physical connection between the church and the "Great Boiler", the door to which is placed directly in the chancel, and further enhanced in the trance-like, ritualistic effects of the spirit of enthusiasm distilled in the "kettles":

A soft liquid oozed into the kettle. [...] It resembled foam on beer; it was all life, but less substance. [...] it operated very singularly. Commencing at the toes it worked upward engrossing the brain. [...] All was rupture of course, in the persons of the initiates; their prejudices vanished or seemed to, and urging close up they evinced a powerful inclination to be amorous [...] But the mad spirit did not stop here; every thing in the room seemed bewitched, chairs, tables, and kettles were all frisking and capering [...] (Holgate 26-7)

Much as in Paulding's work, the machines used by amalgamationists are instruments in the more complex process of transformation into transhumans, whose essential goal is the affirmation and implementation of the ideology.

Though Paulding and Holgate link the dangerous ideas with machines, neither envisages technology as potent enough to be the sole determining influence on the human, while they both underscore the transformative potential of ideologies.

\section{THE DANGER AND FOLLY OF IDEOLOGY}

In both texts transhumans bear signs of madness directly related to their devotion to flawed principles, while the ideologues are presented as stubbornly adhering to those flawed principles despite much evidence of their irrationality. Paulding's critique of Owen contains a bitter contention that the philanthropist's work may do more harm than good. The fact that though unable to understand the master's preaching, the disciples manage to achieve near perfection by unthinkingly following his precepts testifies to the disillusioning similarity between the noble idea and the reality of any factory at the time. The author's implication seems to be that while industrialisation itself inevitably produces an undesirable type of transhumans, people who have undergone a process of extreme reification, Owen's experiment is rendered significantly more harmful by its employment of ideology. The philanthropist earns the author's derision since he preaches, from Paulding's point of 
view, illogical doctrines which further harm his believers, becoming guilty of superimposing nonsense on the damage inflicted by modern life and, essentially, inducing intellectual stupor in already abused people. His original sin lies in trying to reconcile misguided high ideals of perfectibility with the laws of capitalism, thus making the former justify the latter; his ultimate blunder is in imagining he can create a new, superior race of humans by approaching people as manipulable, adjustable machines.

Aiming to expose what he sees as inane thinking, Paulding characterises Owen's proselytizing as ridden with direct contradictions - "I'm sure I should never have thought that it was possible a thing could be exactly what it is not" (55) - and illustrates its effect succinctly with the image of a perfect man-machine crushed to death under the wheels of a carriage in the absence of any figure of authority to instruct him to step aside. Still, the full negative impact of the ideology is best demonstrated by the protagonist's unenviable adventures after he leaves New Lanark. On attempting to convert his newly inherited household to Owen's principles, he is ousted from his own estate by the servants, who use his teachings to prove their right to do so. Next, again on account of his preaching he is placed in solitary confinement in an asylum, cheated out of his money when freed, and then imprisoned. Despite all such dire consequences, the protagonist enthusiastically preaches the new view of society to all and sundry and counters logical arguments with unflagging repetition of memorised phrases.

In Sojourn, the author's preferred mode of baring the folly of ideology is found in its substantiation. While the consequences of miscegenation are grotesquely fleshed out in Boge Bogun, the key incarnation in the text is the Goddess Enthusiasm, "a huge giant, all of twelve feet in height, with fiery eyes, and a hideous jaw, being long, lank, and rattling" (Holgate 24), whose job is to violently control her votaries-believers in racial equality-by "flogging them outrageously" (24) "if they relax in the least in their efforts" (24). Both the giantess and her brainchild — the amalgamating machineryare threatening material forms of the conceptions borne by the preachers' words and by the fumes from the amalgamating "boilers". The same enthusiastic faith in the cause drives the chief abolitionist to believe he can destroy a wall with the might of his commanding will. Still, the high point of Holgate's depiction of faith in the power of abstraction is presumably marked by the war against the slavers shelled by the amalgamationists with "conscience-battering" (Holgate 154) cannonballs comprised of blends of concepts which, frustratingly, make no impression on the target: 
The cartridges [...] contained the following compounds:

Enthusiasm,...15 lbs.

Rage, ... 5

Stubbornness, ... 9

Avarice, ... 6

Pugnacity, ... 12 (Holgate 154)

\section{THE LABORATORIES OF CIRCUMSTANCES}

Evidently, the crucial factor in the coming about of these transhuman mishaps is their immersion in an ideologically controlled environment. Instead of a space of change where humans would enter in their old form and emerge as their superior selves, the texts depict the entire societies as experimental "laboratories" for the formation of the transhuman. The potential malevolence of this idea is perhaps enhanced by the fact that both the societies lack law-enforcement structures. Essentially, the citizens are expected to self-police, and, in both cases, they do, this practice lying at the heart of the transformative process.

In Amalgamation citizens are inculcated with amalgamationist ideas during services (led by a white priest accompanied by his black wife and children) and are treated to public debates on the topic. Mostly, however, the population at large seems determined to keep a close watch on their own contrary inclinations. A man who de-bottles himself in his sleep wanders the corridors of the African House hotel kept awake by pangs of conscience, and the next morning forces himself to attend to a black woman, striving in vain to suppress a discharge of vomit. White citizens are alleged to keep plates of manure by their bedsides to desensitise their olfactory organs; and it is expected that the least attractive black men are to be matched with the handsomest white women at a ball. Social pressure, the preachers' instructions and the citizens' own primed consciences appear to be the main shapers of rules in Amalgamation. This state of affairs is allegorically depicted in the whip-wielding Goddess Enthusiasm and her infernal establishment-grotesque synecdoches for the abstraction of belief in racial equality and for the city itself. Faith in the cause is personified as a harsh mistress who requires obedience to unnatural ideas against the healthy and sane instinct of the white body and mind, while the slave-filled laboratory brimful of an intoxicating, reason-stalling vapour and cries of tortured people stands for the entire city outside. ${ }^{8}$ Every believer in the

\footnotetext{
${ }^{8}$ In the portrayal of the dangerous city Paulding follows gothic conventions: its streets are mist-shrouded and resound with screams of victims of the amalgamating process; they are the
} 
cause the narrator meets feels the scourge of remorse, much like the slaves chastised by the giantess at the "Great Boiler", while their self-disciplining renders the depiction all the more disturbing.

The version of New Lanark projected in Man-Machine is one of a thoroughly planned setting. Children are instructed in the practice of communal selflessness in the playground, adults hear lectures by Owen himself, and those approaching machine-perfection are exhibited as enviable examples. The protagonist's full immersion in this controlled environment results in the production of a transhuman who could well serve as an apt illustration of the workings of Engelsian false consciousness, with the narrator, forever undiscouraged, riding the hobby-horse of his master's ideology. Unceasing devotion to the principles, implicitly presented as an attribute developed by the force of habit in much the same way as is the skill to attend a spinning jenny, remains the spiritus movens behind the protagonist's actions both during his stay in New Lanark and afterwards when he not only self-polices in the absence of the master and fellow man-machines but does his best to spread and implement the new view of society himself despite the harshest criticism and the most arduous misfortunes. Clearly, the carefully planned routine of Owen's community creates a man-machine with a faith not only sufficiently enduring to be maintained outside of the training environment but also powerful enough to try to affect the highly resistant outside world. The author, true to his work's title, depicts the construction of a transhuman fixated on a single fully internalised ideological proposition, forever attempting to recreate the conditions of the home-laboratory irrespective of the outside circumstances. His conspicuous non-belonging in the world at large is matched by his inability to perform any work apart from tending to a spinning jenny. As it appears, his early conditioning is permanent, and his working activity seems durably bound to the twin motion of a machine: "a horsefiddle, which was placed on a pole in the field where I was to be employed. So long as that went, I went; but when the weather was calm, the fiddle stopt, and so did I" (Paulding 141).

In both dystopias the would-be high-tech laboratories and computer rooms are still the stuff of the future while the loci of transformation are, significantly, as much a factory (Paulding) or boiler room (Holgate), as a playground (Paulding) or church (Holgate). It is the very pervasiveness of the transformative influences which lies at the core of the molding of the

loci of encounters with a band of angry armed black men, a ghastly old crone, and an eerie, rabid amalgamation of a horse and a cow stampeding madly through moonlit alleys. 
transhuman in the nineteenth century, apparently marked by the overriding importance of a version of Althusserian Ideological State Apparatuses ${ }^{9}$. By dispensing with repressive structures altogether, Paulding and Holgate imply that the discipline imposed more or less directly by school, religion, various figures of authority and careful management of the immediate environment largely suffices to effect a substantial change. The strength of their message of distrust towards ideology relies on identifying the threat of the new, worse human as enforced by the perhaps illusive and therefore easily dismissed manipulable socio-cultural "circumstances".

\section{COMMUNAL TRANSHUMANITY}

What is perhaps striking from the modern perspective on the goals of transhumanity is that the primary reason for wishing to change people is in both texts the good of the community. While current trans/posthuman arguments seem to rely for their appeal on the advertisement of enhanced individual capacities, and move on from there to speculate on the impact of the change on trans/posthumanity and its environment, the authors of these early nineteenth-century texts identify the reformers as working primarily with a clear bird's-eye vision of a new society. In Paulding, true on this occasion to Owen's actual views, the protagonist realises the transformation into a new version of a human is valid only if it does not infringe on communal equality: "Thus I found to my great mortification, that individual perfectibility, was incompatible with the perfectibility of the whole, and that the only way to preserve 'harmony' was to be no better than other people" (47). The careful attendance to "the happiness of the self" crucial to the Owenite experiment is identified relationally "as the only means of promoting the happiness of the community" (Paulding 53).

In Sojourn, as the primary interest of the novel is miscegenation, its smallest unit of concern is in fact the mixed-race couple and the society populated by them rather than the individual. The changes the white popula-

\footnotetext{
${ }^{9}$ Essentially, Althusser's view that a large body of Ideological State Apparatuses, "Churches, Parties, Trade Unions, families, schools, most newspapers, cultural ventures, etc., etc., are private" ties in with the utopian nature of the projects depicted in both Paulding and Holgate, as well as elsewhere: utopias are frequently treated as social experiments which require the emotional involvement of each member of the community, their individual acceptance and devotion to the cause. In this context it may be expected that Ideological State Apparatuses will be of primary significance to the constituted utopian communities, while Repressive State Apparatuses may be treated as a potentially dispensable last resort.
} 
tion undergoes are all proposed and implemented in the name of an egalitarian society, and their discomfort is treated as a necessary by-product of the process; individual hardship is to be overcome for the sake of a new society.

Paulding's and Holgate's texts respond to both ideological and technological experimentation, which go hand in hand in the era of industrialisation and utopian thinking. The broad inspiration results in a rich and perhaps uneasy mixture of capitalism, communitarianism and technophobia, of abolitionism, miscegenation and machinery, all consolidated by a substantial measure of bioconservatism and a belief in the essential sanity and hardiness of the human mind and body. Crucially, while both works deal with the key transhuman goal of "enhancement of human capacities" (Roden 9), technology seems more of a rhetorically useful ancillary to enhance and concisely illustrate the essential in-humanity of society after the feared change. Nonetheless, although ideology and technology may seem allies when they both inspire the fear of newness and of social transformation in a century which saw the burgeoning of both, the doctor Frankenstein in these dystopias is an ideologue rather than a scientist. What is more, the fact that the space of change into the transhuman is expanded to include the entire communities reflects the reformers' comprehensive view and their interest in community as the unit of prime importance, as well as reflecting the specificity of the transformative force of ideology, which by its nature functions within the larger context of society. The nascency of the transhuman of the period seems intrinsically bound up with changes in the broader entities, the spaces and communities in question, projecting the world as a dangerous laboratory of adjustable circumstances.

\section{WORKS CITED}

Aderman, Ralph M. "James Kirke Paulding as Social Critic." Papers on English Literature and Language 1 (1965): 217-29. Print.

Althusser, Louis. "Ideology and Ideological State Apparatuses." Lenin and Philosophy and Other Essays. Translated by Ben Brewster. New York: Monthly Review Press, 1971. Web.

Blaim, Artur. "Hell upon a Hill: Reflections on Anti-Utopia and Dystopia”. Dystopia(n) Matters: On the Page, on Screen, on Stage. Ed. Fátima Vieira. Newcastle upon Tyne: Cambridge Scholars Publishing, 2013. 80-91. Print.

Carlyle, Thomas. "The Signs of the Times." 1829. Web.

Claeys, Gregory, ed. The Cambridge Companion to Utopian Literature. Cambridge: Cambridge University Press, 2010. Print. 
Gerber, Gerald E. “James Kirke Paulding and the Image of the Machine.” American Quarterly 22 (1970): 736-41. Print.

Holgate, Jerome Bonaparte [pseud. Bolokitten, Oliver, Esq.]. A Sojourn in the City of Amalgamation in the Year of our Lord 19-. New York: published by the author, 1835. Print.

Martin, Charles D. The White African American Body. A Cultural and Literary Theory. New Brunswick, NJ: Rutgers University Press, 2002. Print.

Owen, Robert. A New View of Society. Or, Essays on the Principle of the Formation of the Human Character, and the Application of the Principle to Practice. New York: Richard Taylor and Co., 1813. Web.

Paulding, James Kirke. The Man Machine, or the Pupil of Circumstances. In The Merry Tales of the Three Wise Men of Gotham. New York: G. and C. Carvill, 1826. 21-142. Print.

Rivkin, Julie and Michael Ryan. Literary Theory: An Anthology. Second Edition. Oxford: Blackwell Publishing, 2009. Print.

Roden, David. Posthuman Life. Philosophy at the Edge of the Human. London: Rutledge, 2015. Print.

Roemer, Kenneth M. "Paradise Transformed: Varieties of Nineteenth-Century Utopias." The Cambridge Companion to Utopian Literature. Ed. Gregory Claeys. Cambridge: Cambridge University Press, 2010. 79-106. Print.

Schiller, J. C. Friedrich Von Schiller. Letters Upon the Aesthetical Education of Man, 1795. Web.

Vieira, Fátima, ed. Dystopia(n) Matters: On the Page, on Screen, on Stage. Newcastle upon Tyne: Cambridge Scholars Publishing, 2013. Print.

\section{LABORATORIA OKOLICZNOŚCI I NIEFORTUNNI TRANSLUDZIE. PORAŻKI DOSKONAŁOŚCI W DWÓCH DZIEWIĘTNASTOWIECZNYCH AMERYKAŃSKICH DYSTOPIACH}

\section{Streszczenie}

Artykuł przedstawia analizę dwóch amerykańskich dystopii z początku dziewiętnastego wieku, Człowiek-Maszyna, albo Uczeń Okoliczności (1826) James'a Kirke Paulding'a, oraz Miasto Amalgamacji w Roku Pańskim 19-- (1835) Jerome'a Bonaparte Holgate'a, koncentrując się na reprezentacji wczesnych wersji transczłowieka. Podczas gdy nowela Pauldinga stanowi krytykę New Lanark Roberta Owena, fabryki tekstyliów będącej jednocześnie socjalistycznym eksperymentem, a satyra Holgate'a odnosi się krytycznie do kwestii krzyżowania ras, obydwa utwory wysuwają na plan pierwszy problem nowego człowieka jako produktu ideologicznego.

Słowa kluczowe: ideologia; rasizm; owenizm; transczłowiek. 
